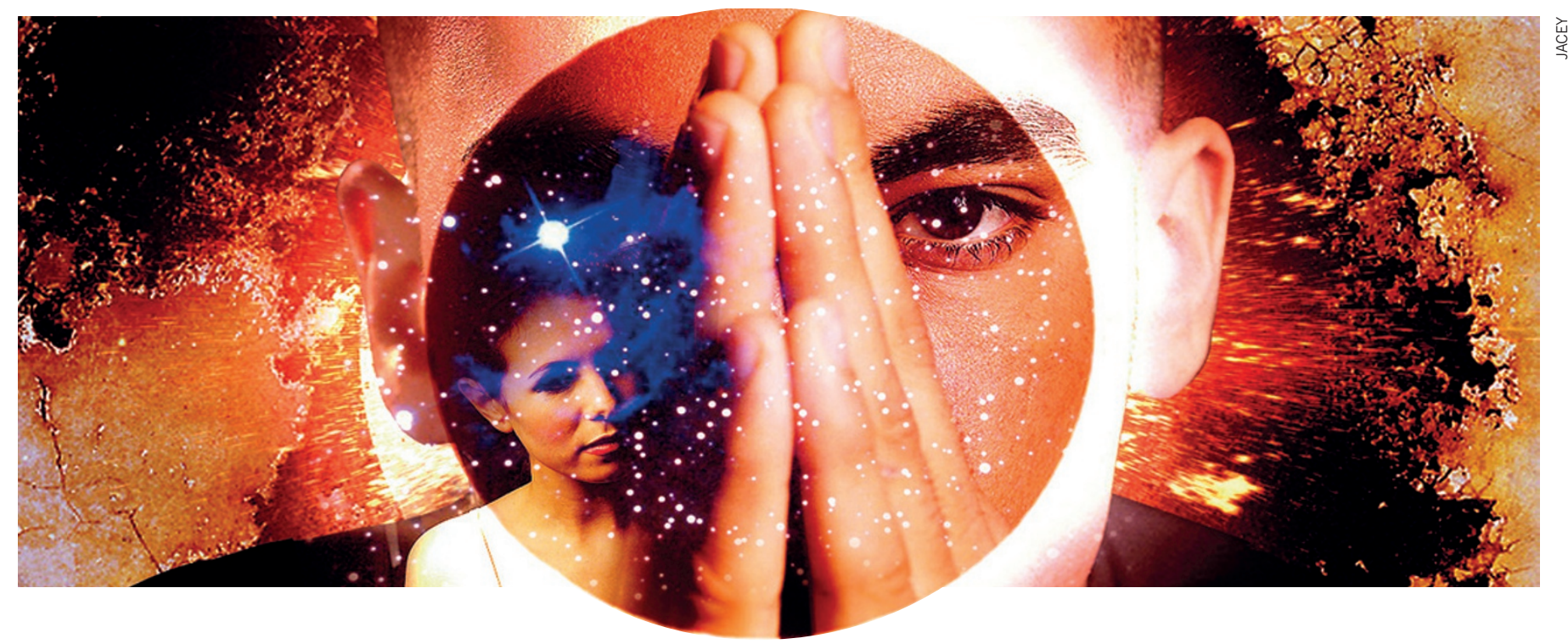

\title{
A ONE-SIDED ARGUMENT
}

The voice of reason.

\section{BY ALEX SHVARTSMAN}

$\mathrm{O}$ ur arguments became one-sided after the aliens crash-landed in Manhattan.

"It was an accident," Colette says. "A tragic mistake. They didn't mean to hurt anyone."

She prattles on and on like this. I sulk.

There may be 7 billion people on Earth, but our planet is mostly uninhabited, full of vast empty spaces, even if you only count the landmass. So the odds of those octopuslooking bastards crashing in one of the most densely populated cities in the world are, what - some fraction of a per cent? A dark cosmic joke, except that there are 20,000 dead people buried under the rubble, and their families aren't laughing.

Colette only sees the best in people, even when they aren't people at all. "They aren't perfect, but they aren't evil, either. It was a rough landing; their ship almost disintegrated on entry. It's not like they wanted to kill anyone."

Captain Sully managed to land a malfunctioning plane in the Hudson River some years back, and he was only human. These aliens, who built vessels capable of reaching another star, should have been able to do better. I bet they just didn't care.

"Years from now, that day won't be remembered for the tragedy and the loss, but as the moment we finally learned that we aren't alone in the Universe." Colette can keep up her side of the argument for hours. Days, even.
We're a real odd couple. I served two tours in Iraq, and she protested against the war. I'm quiet and she's chatty. But it was her non-stop chitchat that got me through the nightmares and the shakes and all the other fun parting gifts I returned home with after the war. PTSD, the doctors called it. I called it hell.

So I listen to her defend the aliens, and whenever I can no longer stand to hear it, I leave the house for a while.

I drive to Sunset Park, our favourite outdoor spot in Brooklyn from back when we were dating. We used to love coming here to take in the New York skyline. I sit at the bench where I proposed, and I stare at where the familiar contours of skyscrapers used to be. Manhattan still burns. Ash wafts across the water.

The alien ship levelled several city blocks downtown. The devastation they caused is worse than any war. Worse than $9 / 11$. If some terrorist did this with a suitcase nuke, we'd be bombing their capital already. But these aliens, we just forgive them and welcome them with open arms? This isn't right.

I inhale the bitter smoke and it reminds me of death and pain and Fallujah. They can't get away with this. Somebody has to make the alien bastards pay.

Back home, I stare at the arsenal laid out on the workbench in my garage. The GLOCK 19 handgun and AR semi-auto- $\rightarrow$ NATURE.COM

Follow Futures: @ @NatureFutures $f$ go.nature.com/mtoodm matic rifle have been there since the day of the crash. A pair of home-made IEDs have joined them since then. I've been busy.

I can get close. I can walk right up to the police barricades that cordon off the ship, and I can push my way past New York's Finest. They probably wouldn't try very hard to stop me; after dealing with the grieving families who show up there every day, the cops must hate the aliens nearly as much as I do. And when I get to the dozens of little octopuses repairing the hull of their ship, like they keep showing on the news, I can open fire. I bet I can take out a good number of them before anyone stops me.

The only thing holding me back is Colette.

She forgives them, utterly and without doubt.

I pace across the garage, and allow Colette's voice to soothe me.

Our arguments became one-sided after the aliens crash-landed in Manhattan. After their gargantuan spaceship crushed Colette's office building. They're one-sided because there's no use talking back to the dead.

All I can do instead is to honour her memory as best I can; to do what I've done every day since I lost her.

I take another longing look at the workbench and walk out of the garage. I go back to the house, back to our bedroom, where Colette's scent still lingers. I close my eyes, listen to her voice inside my head, and try very hard to let her persuade me.

Alex Shvartsman is a writer and game designer from Brooklyn, New York. Read more of his fiction at www.alexshvartsman.com. 